\title{
Rapid, polybaric phenocryst growth in Long Valley basalts during ascent: application of olivine-melt thermometry and hygrometry
}

\author{
J.S.R. JOLLES' \& R.A. LANGE'
}

'Dept. Earth \& Environmental Sciences, University of Michigan, Ann Arbor, MI 48109, USA;

jjolles@umich.edu; becky@umich.edu

The Long Valley volcanic field in eastern California is well known for the eruption of high- $\mathrm{SiO}_{2}$ rhyolite melts, including the voluminous ( $>600 \mathrm{~km}^{3}$ ) Bishop Tuff (BT). The next most abundant magma type in the vicinity, which erupted both before and after the BT, are the Long Valley (LV) basalts, which were derived from subduction-modified lithosphere. A notable feature of the Bishop Tuff rhyolite is its high water content $(\leq 6.5 \mathrm{wt} \%)$, and the primary source of this water must be the associated LV basalts (i.e., those that did not erupt, but transferred their heat and water to the crust at depth), given that the pre-existing granitoid crust contains $<0.6 \mathrm{wt} \% \mathrm{H}_{2} \mathrm{O}$. An outstanding question, therefore, is what is the range of temperatures and water contents of the LV basalts. In this study, olivine-melt thermometry is applied to several, high-MgO (6.6-9.0 wt\%) LV basalts, which contain abundant phenocrysts of olivine, with lesser amounts of cpx (sector-zoned) \pm plagioclase. Histograms of analyzed olivine compositions display a continous, unimodal population in each sample, with the most $\mathrm{Mg}$-rich olivine a match to that predicted on the liquidus by the MELTS thermodynamic model at $\triangle \mathrm{QFM}=+1$. X-ray maps of phosphorous in olivine reveal initial dendritic, growth patterns, which together with the sector-zoning in most clinopyroxene phenocrysts are consistent with rapid, phenocryst growth during ascent. In this study, the $\mathrm{Mg}$ - and Ni-based olivine-melt thermometers from Pu et al. (2017), calibrated on an identical experimental dataset, were applied to the most Mg-rich olivine in each sample and a melt with a composition of the whole rock. Because the Nithermometer is independent of water content, it provides the actual temperature $\left( \pm 29^{\circ} \mathrm{C}\right)$ at the onset of olivine crystallization in each of the LV basalts $\left(1170-1060^{\circ} \mathrm{C}\right)$, whereas the $\mathrm{Mg}$-thermometer gives the temperature under anhydrous conditions and thus allows $\Delta \mathrm{T}\left(=\mathrm{T}_{\mathrm{Mg}}-\mathrm{T}_{\mathrm{Ni}}=\right.$ depression of liquidus due to water) to be obtained. The average $\Delta \mathrm{T}$ for all samples is $\sim 88( \pm 14){ }^{\circ} \mathrm{C}$, which leads the $\mathrm{H}_{2} \mathrm{O}$-corrected Mg-thermometer of Putirka et al. (2007) to calculate $\mathrm{H}_{2} \mathrm{O}$ contents of 3-5 (avg=4) wt $\%$. The average minimum water content is $2.4 \mathrm{wt} \%$ (Pu et al., 2017). 